\title{
3 Research Square

\section{Niacin mitigates rumen epithelial damage in vivo by inhibiting rumen epithelial cell apoptosis on a high concentrate diet}

\section{Zhen Gao}

Jiangxi Agricultural University

Yanjiao Li ( $\square$ yanjiaoli221@163.com )

Jiangxi Agricultural University https://orcid.org/0000-0002-5309-0295

Chao Xu

Jiangxi Agricultural University

Dan Luo

Jiangxi Agricultural University

Qinghua Qiu

Jiangxi Agricultural University

Ke Pan

Jiangxi Agricultural University

Xiaowen Xiong

Jiangxi Agricultural University

Mingren Qu

Jiangxi Agricultural University

Kehui Ouyang

Jiangxi Agricultural University

\section{Research Article}

Keywords: apoptosis, high concentrate diet, niacin, oxidative stress, rumen epithelial cell

Posted Date: September 13th, 2021

DOl: https://doi.org/10.21203/rs.3.rs-884917/v1

License: (c) (1) This work is licensed under a Creative Commons Attribution 4.0 International License. Read Full License

Version of Record: A version of this preprint was published at Veterinary Research Communications on January 25th, 2022. See the published version at https://doi.org/10.1007/s11259-022-09885-9. 


\section{Abstract}

To investigate the effects of niacin on rumen fermentation, rumen epithelial antioxidant activity, and rumen epithelial cell apoptosis on high concentrate $(\mathrm{HC})$ diets, nine male Hu sheep were randomly divided into: low concentrate diet (LC; concentrate : forage $(C: F)=20: 80$, high concentrate diet $(H C ; C: F=80: 20)$, and $\mathrm{HCN}$ diet ( $\mathrm{HC}$ diet + niacin at $800 \mathrm{mg} / \mathrm{kg}$ diet air-dry matter). Compared with the LC group, the HC group had a lower rumen $\mathrm{pH}$, increased volatile fatty acids and lactic acid in the rumen, reduced activity of antioxidant enzymes and total antioxidant capacity, and increased malondialdehyde content in the rumen epithelium $(P<0.05)$. Rumen epithelial papilla morphology was decreased, and apoptosis-related indicators and serum inflammatory cytokines were increased in the HC group over the LC group $(P<0.05)$. Compared with the $\mathrm{HC}$ diet, the $\mathrm{HCN}$ diet increased rumen $\mathrm{pH}$, rumen epithelium antioxidant capacity, and rumen epithelial papilla morphology, decreased rumen lactate content, serum inflammatory cytokines, and apoptosis-related indicators $(P<0.05)$. Therefore, adding $800 \mathrm{mg} / \mathrm{kg}$ niacin helped protect against rumen epithelial damage by avoiding drastic changes in the rumen environment and improved rumen epithelial antioxidant capacity to inhibit rumen epithelial cell apoptosis in sheep on a HC diet.

\section{Introduction}

For ruminants, the integrity of the rumen epithelial structure is necessary for the executive function of rumen digestion, absorption, and epithelial barriers (John et al. 2011). Thus, maintenance of the integrity of rumen epithelium is crucial for the ruminant growth, immunity, and health. However, in current ruminant production, excess intake of high concentrate $(\mathrm{HC})$ diets for ruminant frequently causes volatile fatty acids (VFA) accumulation in the rumen, which exceed VFA absorption of rumen epithelium (Li et al. 2019), leads to lower rumen $\mathrm{pH}$ and finally results in subacute ruminal acidosis (SARA) (Sun et al. 2018). The prolonged low $\mathrm{pH}$ condition promotes some rumen microorganism death, and some toxic metabolite release (e. g. lipopolysaccharides: LPS), which then results in the disruption of the ruminal epithelial structural integrity and further damages the barrier function of the ruminal mucosa (Mao et al. 2015; Plaizier et al. 2012; Sun et al. 2018). Subsequently, these abnormal metabolites and pathogenic microorganisms migrate into the blood through the damaged rumen mucosa, leading to immunosuppression and an inflammatory response in the animal, which ultimately affect the health and production performance of ruminants (Nagaraja and Titgemeyer 2007; Plaizier et al. 2012). Therefore, inhibiting SARAinduced rumen mucosal damage while maintaining the integrity of the ruminal epithelial cells is a formidable challenge that may improve ruminant health and production performance.

The balance between cellular apoptosis and proliferation is essential for maintaining the integrity and its normal function of mucous membrane cells. Nevertheless, excessive epithelial apoptosis disrupts the barrier functions of the intestinal epithelium and subsequently contributes to intestinal hyperpermeability (Günther et al. 2013). Moreover, recent research has shown that apoptosis and damage of rumen epithelium are simultaneous during long-term high-concentrate diet feeding (Dai et al. 2020). Herein, we speculated that inhibition of rumen epithelial cell apoptosis might improve the rumen mucosal barrier structure and function. 
Niacin as a precursor for the coenzymes NAD and NADP in vivo, can participate in mitochondrial respiration and have redox functions. Niacin has been shown to raise intracellular poly ADP-ribose polymerase (PARP) and cell viability (Khafipour et al. 2009). Furthermore, niacin may increase the cellular content of glutathione, suppresses the efflux of cytochrome-C (Cyt-C), and repairs the shear of PARPrelated proteins, resulting in inhibition of cellular apoptosis (Tang et al. 2008). It was reported that niacin had anti-oxidative and anti-inflammatory functions that would help against the oxidative stress and inflammation occur in periparturient cow or beef cattle fed HC diet (Bühler et al. 2018; Luo et al. 2019a). One previous study has reported that adding $40 \mathrm{mM}$ niacin can inhibit rumen epithelial cells apoptosis induced by butyrate in vitro by reducing intracellular oxidative stress, inhibiting the activation of caspase3 and p53, and repairing DNA damage (Luo et al. 2019b). However, the effect of niacin on rumen epithelial cell apoptosis in ruminants on a $\mathrm{HC}$ diet in vivo has not been reported.

Hu sheep is a predominant breed for meat-producing in China because of its high meat production performance and good meat quality, which has been reared on a large scale in intensive production systems (Wang et al. 2017). While intensive Hu sheep farming are prone to develop SARA, therefore, to study the effects of niacin on the prevention and treatment of SARA in Hu sheep are thus of great importance. This study aimed to investigate the effects of the supplementation of niacin on rumen fermentation, rumen epithelial antioxidant activity, blood inflammatory cytokines, apoptotic index of rumen epithelium cells, and apoptosis-related gene expressions in sheep fed a HC diet.

\section{Materials And Methods}

\section{Animal treatments and experimental diets}

Nine, 7 month old, healthy, male Hu sheep of a similar body weight $(34 \pm 3 \mathrm{~kg})$ with permanent rumen fistulas were randomly allocated to three diets: a low concentrate diet (LC; the ratio of concentrate and forage (C:F) was 20:80, a high concentrate diet (HC; C:F was 80:20) and the HC and niacin diet (HCN, HC diet + niacin at $800 \mathrm{mg} / \mathrm{kg}$ diet air-dry matter). The niacin (purity $\geq 99 \%$ ) was provided by the Tianjin Zhongrui Pharmaceutical Co., Ltd. China, and was non-bypassed niacin. Each group consisted of three replicates with one sheep per replicate (pen). The test period lasted 11 days, including 8 days of the pretrial period and 3 days of the experimental period. The sheep of the LC group were fed with the LC diet during the 11 days of test period. The sheep of the HC and HCN groups were fed with the LC diet during the first 7 days of the pre-trial period. Feed was then withdrawn for 1 days, and then sheep received the $\mathrm{HC}$ diet and $\mathrm{HCN}$ diet for 3 days of the experimental period to induce subacute acidosis (Goad et al. 1998). The diet was designed based on the Chinese Feeding Standards for Meat Sheep (NY/T 8162004). The LC diet was formulated to meet the nutrient requirements of $0.05 \mathrm{~kg}$ daily gain in $30-35 \mathrm{~kg}$ male sheep. The $\mathrm{HC}$ diet was formulated to meet the nutrient requirements of $0.2 \mathrm{~kg}$ daily gain in $30-35$ $\mathrm{kg}$ male sheep. The composition and nutrient levels of the LC and HC diet are presented in Table 1. In the $\mathrm{HCN}$ diet, niacin was mixed into the concentrate. After that, the concentrate was combined with the milled forage to make a granular total mixed ration (TMR). The amount of niacin added to the HC diet referred to our previous study (Luo et al. 2017). The TMR was provided twice daily. 
Table 1

Composition and nutrient levels of experimental diet (air-dry basis, \%)

\begin{tabular}{|c|c|c|}
\hline \multirow[t]{2}{*}{ Items } & \multicolumn{2}{|l|}{ Diet $^{1}$} \\
\hline & LC & $\mathrm{HC}$ and $\mathrm{HCN}$ \\
\hline \multicolumn{3}{|l|}{ Ingredients } \\
\hline Peanut straw & 80.0 & 20.0 \\
\hline Corn meal & 12.0 & 52.3 \\
\hline Wheat bran & 3.3 & 13.6 \\
\hline Soybean meal & 1.0 & 4.0 \\
\hline Cottonseed & 2.0 & 8.0 \\
\hline Limestone & 0.2 & 0.6 \\
\hline Salt & 0.5 & 0.5 \\
\hline Premix ${ }^{2}$ & 1.0 & 1.0 \\
\hline Total & 100 & 100 \\
\hline \multicolumn{3}{|l|}{ Nutrient levels } \\
\hline Dry matter & 89.32 & 86.92 \\
\hline Crude protein & 11.78 & 14.57 \\
\hline NDF & 51.38 & 24.26 \\
\hline$A D F$ & 35.79 & 13.74 \\
\hline Calcium & 0.59 & 0.64 \\
\hline Phosphorus & 0.25 & 0.46 \\
\hline $\mathrm{DE}^{3}(\mathrm{MJ} / \mathrm{kg})$ & 10.78 & 14.49 \\
\hline \multicolumn{3}{|c|}{${ }^{1}$ Diet: $\mathrm{LC}=$ low concentrate diet; $\mathrm{HC}=$ high concentrate diet. } \\
\hline \multicolumn{3}{|c|}{$\begin{array}{l}{ }^{2} \text { The premix provided per kilogram of diet: } 6500 \mathrm{IU} \text { of VD } 3,32000 \mathrm{IU} \text { of VE, } 236000 \mathrm{IU} \text { of VA, } 475 \mathrm{mg} \\
\text { of copper as copper sulphate, } 1575 \mathrm{mg} \text { of zinc as zinc oxide, } 11.5 \mathrm{mg} \text { of selenium as sodium selenite } \\
29.5 \mathrm{mg} \text { of iodate as calcium iodate, } 3125 \mathrm{mg} \text { of iron as iron sulphate, } 2435 \mathrm{mg} \text { of manganese as } \\
\text { manganous oxide, } 6.25 \mathrm{mg} \text { of cobalt as cobalt chloride, } 60 \mathrm{mg} \text { of } \mathrm{Mg} \text { as magnesium oxide. }\end{array}$} \\
\hline
\end{tabular}

Feed intake 
In the test period, the feed weight and $2 \mathrm{~h}$ postprandial residual feed weight of each sheep were recorded accurately to calculate the daily feed intake. The differences in feed intake of the three groups each day were analysed.

\section{Samples collection}

The blood, rumen fluid, and rumen abdominal bursa samples were collected. At the end of the feeding experiment, after a $12 \mathrm{hr}$ fast (the next morning), before morning feeding, blood sample was taken from the sheep jugular vein, centrifuged $\left(3000 \mathrm{~g}, 10,4^{\circ} \mathrm{C}\right)$ to obtain serum samples, and then stored at $-20^{\circ} \mathrm{C}$.

After blood sampling, before morning feeding, approximately $100 \mathrm{~mL}$ of rumen fluid samples were collected from the upper, middle, and lower sites in the rumen. The rumen fluid samples were mixed homogeneously and then filtered through four layers of cheesecloth and immediately measured for $\mathrm{pH}$ using a Leici PHS-3C pH meter (Leici, Shanghai, China). Three replicates of each sample were measured to calculate the average value of rumen fluid $\mathrm{pH}$. Then, a subsample $8 \mathrm{~mL}$ of rumen fluid was used for VFA analysis (mixed with $2 \mathrm{~mL}$ of $25 \%$ (wt/vol) metaphosphoric acid). Another subsample of rumen fluid was used for lactic acid analysis. These samples were frozen at $-20^{\circ} \mathrm{C}$.

All sheep were sacrificed following electrical stunning and exsanguination after blood sampling and rumen fluid collection. The abdominal cavity of the sheep was opened and partial samples of rumen epithelium were excised from the caudoventral blind sac and washed three times in precooled phosphate buffered saline. The rumen epithelium samples were divided into two portions, the first sample was placed in $10 \%$ neutral buffered formalin at room temperature for $24 \mathrm{hr}$ to examine tissue morphology. The other subsample of rumen epithelium was minced with scissors and frozen in liquid nitrogen in $2 \mathrm{~mL}$ tubes and stored at $-80^{\circ} \mathrm{C}$ for antioxidant activity analysis and determination of apoptosis-related gene expression.

\section{Volatile fatty acids and lactic acid determination}

The VFA content in the rumen fluid was evaluated by high-performance liquid chromatography (HPLC). Briefly, after thawing, the rumen fluid was mixed in a 1:1 ratio with chromatographic grade methanol and then centrifuged $\left(12,500 \mathrm{~g}, 4^{\circ} \mathrm{C}, 10 \mathrm{~min}\right)$. The supernatant was filtered through a $0.45 \mu \mathrm{m}$ filter, injected into a Waters-2489 Alliance HPLC system (Waters, Milford, MA, USA) with a Kromasil 5 um C18 column $(250 \times 4.6 \mathrm{~mm})$ (Feinano, Tianjin, China). Mobile phase A, HPLC grade methanol, mobile phase B, phosphate buffer $\left(\mathrm{KH}_{2} \mathrm{PO}_{4} / \mathrm{H}_{3} \mathrm{PO}_{4} ; 20 \mathrm{mmol} / \mathrm{L}\right.$, $\left.\mathrm{pH} 2.37\right)$, mobile $\mathrm{A} /$ mobile $\mathrm{B}, 15 \% / 85 \%$. Column temperature: $30^{\circ} \mathrm{C}$; injection volume: $10 \mu \mathrm{L}$; UV detection: $214 \mathrm{~nm}$; characteristic running time: $15 \mathrm{~min}$; flow-rate: $1.0 \mathrm{~mL} / \mathrm{min}$. The sample measurement was set to auto-sequence injection. Peaks were identified and quantified using standard curves established according to the method described by Zhang et al. (2010). Each sample was measured three replicates to calculate the average values of VFA.

The rumen fluid lactic acid concentrate was measured using a commercial lactic acid kit (Nanjing Jiancheng Bioengineering Institute, Nanjing, China). Each sample was measured three replicates to calculate the average value. 


\section{Rumen epithelium antioxidant activity determination}

For antioxidant activity assays, frozen rumen epithelium samples were homogenized in ice-cold physiological saline (1:9) for $1 \mathrm{~min}$ and then centrifuged $\left(2,700 \mathrm{~g}, 4^{\circ} \mathrm{C}, 10 \mathrm{~min}\right)$. The supernatants were used to measure the total antioxidant capacity (T-AOC), the activity of catalase (CAT), superoxide dismutase (SOD), and glutathione peroxidase (GSH-Px), and the content of malondialdehyde (MDA). The content of total protein in the rumen epithelium was determined using a total protein kit (Nanjing Jiancheng Bioengineering Institute, Nangjing, China) according to the instructions of the manufacturer. Antioxidant indices in the rumen epithelium were determined by commercial CAT, GSH-Px, SOD, T-AOC, and MDA kits (Nanjing Jiancheng Bioengineering Institute), and were normalized by total protein concentration in the rumen epithelium according to the instructions of the manufacturer. Each sample was measured three replicates to calculate the average values of those antioxidant indices.

\section{Morphological structure of rumen epithelium}

To determine the structure of the rumen epithelium, the rumen epithelial samples in $10 \%$ neutral buffered formalin were taken out and then dehydrated, paraffin-embedded, sliced, haematoxylin-eosin stained and sealed. Photographs were taken of the sections using a microscope (Motic BA210, Xiamen, China) at a magnification of 100x. The pictures, including villus height, width, and cuticular thickness, were analysed using the Image-ProPlus6.0 analysis system. The papilla width was measured at the middle of the villus. The papilla length was measured from the base of the villus to the highest point of the villus. Five fields were randomly captured in each section.

\section{Serum inflammatory cytokines determination}

The contents of serum interleukin-1 $\beta$ (IL-1 $\beta$ ), IL-4, IL-6, IL-10, and tumour necrosis factor- $\alpha$ (TNF- $\alpha$ ) were measured using commercial sheep IL-1 $\beta$, IL-4, IL-6, IL-10, and TNF- $\alpha$ Elisa kits (Nanjing Jiancheng Bioengineering Institute). Each sample was measured three replicates to calculate the average values of the serum inflammatory cytokine levels.

\section{Rumen epithelium cell apoptotic index analysis}

To analyse the apoptotic index of rumen epithelial cells, the rumen epithelial samples in $10 \%$ neutral buffered formalin were taken out and then dehydrated, paraffin-embedded, and sliced. The TUNEL (terminal deoxynucleotidyl transferase dUTP nick end labelling) staining of rumen epithelial cells was performed using the TUNEL Apoptosis Detection kit (Wuhan Boster Biological Technology, Ltd., Wuhan, China). Photographs were taken of the sections with a microscope (Motic BA210, Xiamen, China) at a magnification of $400 \times$. The TUNEL-positive brown cells were considered apoptotic cells. The apoptotic index was calculated and five views were captured in each section.

Apoptotic index $=$ (number of apoptotic cells $/$ number of total cells $) \times 100 \%$ Eq. 1

Rumen epithelium apoptosis-related genes expressions 
Total RNA was extracted from frozen rumen epithelium using Trizol reagent (Thermo Fisher Scientific) according to the manufacturer's protocol. The purity and quantity of total RNA were measured using a TU-1901 spectrophotometer (Beijing Purkinje General Instrument Co., Ltd. China) at 260 and $280 \mathrm{~nm}$, and the 260/280 ratios at 1.9-2.0 and the 260/230 ratios at 2.0-2.2 were used in the subsequent polymerase chain reaction (PCR). Total RNA was transcribed to CDNA using RevertAID reverse transcriptase (Thermo Scientific), according to the manufacturer's instructions. The mRNA expressions of apoptosis-related genes were analyzed as described by Li et al. (2021). Primers used for mRNA expression were presented in Table 2. 
Table 2

PCR amplification primer design

\begin{tabular}{|c|c|c|c|}
\hline Gene $^{1}$ & Primer sequence $\left(5^{\prime}\right.$ to $\left.3^{\prime}\right)$ & $\begin{array}{l}\text { Product size } \\
\text { (bp) }\end{array}$ & $\begin{array}{l}\text { GenBank accession } \\
\text { no. }\end{array}$ \\
\hline \multirow[t]{2}{*}{ GAPDH } & $\begin{array}{l}\text { Forward: 5'-AGGTTGTCTCCTGCGACTTCA- } \\
3^{\prime}\end{array}$ & \multirow[t]{2}{*}{132} & \multirow[t]{2}{*}{ NM_001190390.1 } \\
\hline & Reverse: 5'-CCCTGTTGCTGTAGCCGAAT-3' & & \\
\hline \multirow[t]{2}{*}{ Fas } & $\begin{array}{l}\text { Forward: 5'-CTCTGAGGGGCTGAGATTGA- } \\
3^{\prime}\end{array}$ & \multirow[t]{2}{*}{107} & \multirow[t]{2}{*}{ NM_001123003.1 } \\
\hline & Reverse: 5'-GTTTGCCAGGAGGACAAGG-3' & & \\
\hline \multirow[t]{2}{*}{$\mathrm{Bcl}-2$} & $\begin{array}{l}\text { Forward: 5'-TGTTTGATTTCTCCTGGCTGT- } \\
3^{\prime}\end{array}$ & \multirow[t]{2}{*}{145} & \multirow[t]{2}{*}{ XM_012103831.2 } \\
\hline & $\begin{array}{l}\text { Reverse: 5'-ACTGCTTTCACGAACCTTTTG- } \\
3^{\prime}\end{array}$ & & \\
\hline \multirow[t]{2}{*}{ Bax } & Forward: 5'-TTCCGACGGCAACTTCAAC-3' & \multirow[t]{2}{*}{244} & \multirow[t]{2}{*}{ XM_015100639.1 } \\
\hline & Reverse: 5'-GAGCACTCCAGCCACAAAGA-3' & & \\
\hline \multirow[t]{2}{*}{ Caspase8 } & Forward: 5'-AAAATGCCCTTCССTTGTTG-3' & \multirow[t]{2}{*}{110} & \multirow[t]{2}{*}{ XM_012142500.2 } \\
\hline & $\begin{array}{l}\text { Reverse: 5'- } \\
\text { CTTCCCTCTGTTCTGAGTCGGT-3' }\end{array}$ & & \\
\hline \multirow[t]{2}{*}{ Caspase3 } & Forward: 5'-GCAGCAAACCTCAGGGAAA-3' & \multirow[t]{2}{*}{154} & \multirow[t]{2}{*}{ XM_015104559.1 } \\
\hline & Reverse: 5'-CATGGCTTAGAAGCACGCA-3' & & \\
\hline \multirow[t]{2}{*}{ Caspase9 } & Forward: 5'-TGTTGCCGTTTCCTTCTCC-3' & \multirow[t]{2}{*}{111} & \multirow[t]{2}{*}{ XM_015099300.1 } \\
\hline & $\begin{array}{l}\text { Reverse: 5'-CTAGCACTTCGCTTTCTGGTG- } \\
3^{\prime}\end{array}$ & & \\
\hline \multirow[t]{2}{*}{ p53 } & $\begin{array}{l}\text { Forward: 5'-CAGGAGACATTTTCCGACTTG- } \\
3^{\prime}\end{array}$ & \multirow[t]{2}{*}{122} & \multirow[t]{2}{*}{ NM_001009403.1 } \\
\hline & Reverse:5'-TCATCCAGCCAGGTGACAA-3' & & \\
\hline
\end{tabular}

\section{Statistical analysis}

All data analyses were performed by One-Way ANOVA using SPSS 17.0 statistical software (SPSS Inc., Chicago, IL, USA). The significance of differences among treatments was evaluated using Tukey's tests. All results were presented as the mean \pm standard deviation (SD). $P$-values $<0.05$ were considered statistically significant. 


\section{Results}

\section{Feed intake}

The feed intake of the LC group did not change, while that of the $\mathrm{HC}$ and $\mathrm{HCN}$ group fell gradually during the $3 \mathrm{~d}$ of the experimental period (Fig. 1). On the first day, the $\mathrm{HC}$ and $\mathrm{HCN}$ group had significantly higher (16.7\% and $26 \%$, respectively) feed intake than the LC group $(P<0.05)$. Then the HC and HCN groups had numerically lower ( $24 \%$ and $6.5 \%$, respectively) feed intake than the LC group on the second day, and a significantly lower (37.7\% and $26.7 \%$, respectively) feed intake than the LC group on the third day $(P<$ 0.05).

\section{Rumen fermentation}

The rumen $\mathrm{pH}$ value was lower in the $\mathrm{HC}$ and $\mathrm{HCN}$ groups than in the $\mathrm{LC}$ group $(P<0.05)$, while the rumen $\mathrm{pH}$ was higher in the HCN group than the HC group $(P<0.05)$ (Table 3$)$. The $\mathrm{HC}$ and $\mathrm{HCN}$ groups had a higher content of acetate, propionate, butyrate, total VFA, and lactate in the rumen fluid than the LC group $(P<0.05)$, while the content of acetate, propionate, butyrate, total VFA, and lactate in the rumen fluid were lower in the $\mathrm{HCN}$ group than the $\mathrm{HC}$ group $(P<0.05)$. The $\mathrm{HC}$ group had a lower acetate/propionate ratio than the LC group $(P<0.05)$, and there was no difference between the HC group and the HCN group or the LC group and HCN group. 
Table 3

Effects of diet treatments on the rumen fermentation of sheep

\begin{tabular}{|c|c|c|c|}
\hline \multirow[t]{2}{*}{ Items $^{2}$} & \multicolumn{3}{|l|}{ Diet $^{1}$} \\
\hline & LC & $\mathrm{HC}$ & $\mathrm{HCN}$ \\
\hline Ruminal pH & $6.85 \pm 0.05^{\mathrm{a}}$ & $5.95 \pm 0.08^{c}$ & $6.28 \pm 0.05^{b}$ \\
\hline Acetate $(\mathrm{mmol} / \mathrm{L})$ & $35.39 \pm 1.18^{c}$ & $70.24 \pm 5.87^{a}$ & $50.34 \pm 2.92^{b}$ \\
\hline Propionate (mmol/L) & $8.75 \pm 1.35^{\mathrm{c}}$ & $28.76 \pm 9.03^{a}$ & $15.11 \pm 2.87^{b}$ \\
\hline Acetate/Propionate & $4.11 \pm 0.05^{\mathrm{a}}$ & $2.59 \pm 0.61^{b}$ & $3.43 \pm 0.66^{\mathrm{ab}}$ \\
\hline Butyrate (mmol/L) & $4.27 \pm 0.44^{\mathrm{c}}$ & $18.85 \pm 4.69^{a}$ & $7.84 \pm 1.13^{b}$ \\
\hline TVFA (mmol/L) & $48.42 \pm 2.47^{c}$ & $117.86 \pm 19.50^{\mathrm{a}}$ & $73.29 \pm 3.60^{b}$ \\
\hline Lactate acid (mmol/L) & $0.21 \pm 0.22^{c}$ & $0.43 \pm 0.05^{\mathrm{a}}$ & $0.30 \pm 0.02^{b}$ \\
\hline \multicolumn{4}{|c|}{ Mean values with different letters were significantly different $(P<0.05)$. } \\
\hline \multicolumn{4}{|c|}{$\begin{array}{l}{ }^{1} \text { Diet: } \mathrm{LC}=\text { low concentrate diet; } \mathrm{HC}=\text { high concentrate diet; } \mathrm{HCN}=\mathrm{HC}+800 \mathrm{mg} / \mathrm{kg} \text { niacin in the fee } \\
\text { concentrate. }\end{array}$} \\
\hline
\end{tabular}

\section{Rumen epithelium antioxidant activity}

The activity of CAT, GSH-Px, SOD, and T-AOC of rumen epithelium was lower in the HC and HCN groups than in the LC group $(P<0.05)$, while the activity of CAT, GSH-Px, and T-AOC was higher in the HCN group compared to the HC group $(P<0.05)$ (Table 4). However, there was no difference in SOD activity between the $\mathrm{HC}$ and the HCN group. Compared to the LC group, the $\mathrm{HC}$ and $\mathrm{HCN}$ group had a higher content of MDA $(P<0.05)$, while the content of MDA was lower in the HCN group than the HC group $(P<0.05)$. 
Table 4

Effects of diet treatments on the rumen epithelium antioxidant activity of sheep

\begin{tabular}{|c|c|c|c|}
\hline \multirow[t]{2}{*}{ Items $^{2}$} & \multicolumn{3}{|l|}{$\operatorname{Diet}^{1}$} \\
\hline & LC & $\mathrm{HC}$ & $\mathrm{HCN}$ \\
\hline CAT (U/mg of protein) & $3.62 \pm 0.18^{\mathrm{a}}$ & $1.65 \pm 0.12^{\mathrm{c}}$ & $2.55 \pm 0.15^{b}$ \\
\hline GSH-Px (U/mg of protein) & $538.28 \pm 33.86^{\mathrm{a}}$ & $144.02 \pm 24.46^{c}$ & $235.37 \pm 25.18^{b}$ \\
\hline $\mathrm{SOD}(\mathrm{U} / \mathrm{mg}$ of protein) & $233.99 \pm 16.38^{\mathrm{a}}$ & $162.65 \pm 10.17^{b}$ & $171.52 \pm 24.56^{\mathrm{b}}$ \\
\hline T-AOC (U/mg of protein) & $2.34 \pm 0.15^{a}$ & $0.59 \pm 0.13^{c}$ & $1.43 \pm 0.28^{b}$ \\
\hline MDA (nmol/mg of protein) & $1.66 \pm 0.11^{\mathrm{c}}$ & $3.59 \pm 0.22^{\mathrm{a}}$ & $2.19 \pm 0.15^{b}$ \\
\hline \multicolumn{4}{|c|}{ Mean values with different letters were significantly different $(P<0.05)$. } \\
\hline \multicolumn{4}{|c|}{$\begin{array}{l}{ }^{1} \text { Diet: } \mathrm{LC}=\text { low concentrate diet; } \mathrm{HC}=\text { high concentrate diet; } \mathrm{HCN}=\mathrm{HC}+800 \mathrm{mg} / \mathrm{kg} \text { niacin in the feed } \\
\text { concentrate. }\end{array}$} \\
\hline $\begin{array}{l}{ }^{2} \mathrm{CAT}=\text { catalase; } \mathrm{GSH}-\mathrm{Px}= \\
\text { antioxidant capacity; MDA }\end{array}$ & $\begin{array}{l}\text { le peroxidase; } \mathrm{S} \\
\text { aldehyde. }\end{array}$ & peroxide dism & $A O C=$ total \\
\hline
\end{tabular}

\section{Rumen epithelium papilla morphology}

In the LC group, normal ruminal mucosa was observed. There was mucosal shedding and superficial submucosal congestion in the sheep fed with the HC diet. In the HCN group, only mild mucosal shedding was observed. The papilla length, width (Fig. 2b), and cuticular layer thickness (Fig. 2c) of rumen epithelium were lower in the HC and HCN groups than in the LC group $(P<0.05)$, while the HCN group had a higher papilla length, width, and cuticular layer thickness than the $\mathrm{HC}$ group $(P<0.05)$ (Fig. 2).

\section{Serum inflammatory cytokines}

Compared with the LC group, the HC and HCN groups had higher levels of IL-1 $\beta$, IL-4, IL-6, IL-10, and TNF$a$ in the serum $(P<0.05)$, while the levels of IL-1 $\beta, I L-4, I L-6, I L-10$, and TNF- $\alpha$ in the serum were lower in the HCN group than in the HC group $(P<0.05)$ (Table 5). 
Table 5

Effects of diet treatments on the serum inflammatory cytokines of sheep

\begin{tabular}{|c|c|c|c|}
\hline \multirow[t]{2}{*}{ Items $^{2}$} & \multicolumn{3}{|l|}{ Diet $^{1}$} \\
\hline & LC & $\mathrm{HC}$ & $\mathrm{HCN}$ \\
\hline IL-1ß (ng/L) & $14.09 \pm 2.66^{c}$ & $55.45 \pm 2.33^{a}$ & $31.54 \pm 3.77^{b}$ \\
\hline IL-6 (ng/L) & $70.86 \pm 2.90^{c}$ & $532.28 \pm 28.64^{a}$ & $297.17 \pm 58.93^{b}$ \\
\hline TNF-a (ng/L) & $123.65 \pm 15.13^{c}$ & $484.75 \pm 33.78^{a}$ & $250.73 \pm 30.85^{b}$ \\
\hline $\mathrm{IL}-4(\mathrm{ng} / \mathrm{L})$ & $167.08 \pm 62.22^{c}$ & $982.30 \pm 13.74^{\mathrm{a}}$ & $388.31 \pm 73.67^{b}$ \\
\hline IL-10 (pg/mL) & $161.84 \pm 48.09^{c}$ & $562.36 \pm 26.45^{\mathrm{a}}$ & $276.93 \pm 52.17^{b}$ \\
\hline \multicolumn{4}{|c|}{ Mean values with different letters were significantly different $(P<0.05)$. } \\
\hline \multicolumn{4}{|c|}{$\begin{array}{l}{ }^{1} \text { Diet: } \mathrm{LC}=\text { low concentrate diet; } \mathrm{HC}=\text { high concentrate diet; } \mathrm{HCN}=\mathrm{HC}+800 \mathrm{mg} / \mathrm{kg} \text { niacin in the feec } \\
\text { concentrate. }\end{array}$} \\
\hline
\end{tabular}

\section{Rumen epithelial cell apoptotic index}

Compared with the LC group, the $\mathrm{HC}$ and $\mathrm{HCN}$ group had a higher apoptotic index of rumen epithelial cells $(P<0.05)$, while the apoptotic index was lower in the HCN group than in the HC group $(P<0.05)$ (Fig. 3).

\section{Rumen epithelal apoptosis-related genes expressions}

The mRNA expression of Fas, BCl-2, Bax, Caspase-3, Caspase-8, Caspase-9, and p53, and the ratio of Bcl$2 / B a x$ expression in the rumen epithelium was higher in the $\mathrm{HC}$ and $\mathrm{HCN}$ group than the $\mathrm{LC}$ group $(P<$ $0.05)$, while mRNA expression of the genes and the ratio of $B C l-2 / B a x$ expression were lower in the $\mathrm{HCN}$ group than the $\mathrm{HC}$ group $(P<0.05)($ Table 6$)$. 
Table 6

Effects of diet treatments on the apoptosis-related genes expressions in rumen epithelium of sheep

\begin{tabular}{|c|c|c|c|}
\hline \multirow[t]{2}{*}{ Items $^{2}$} & \multicolumn{3}{|l|}{ Diet $^{1}$} \\
\hline & LC & $\mathrm{HC}$ & $\mathrm{HCN}$ \\
\hline Fas & $0.61 \pm 0.17^{c}$ & $2.16 \pm 0.26^{a}$ & $1.08 \pm 0.23^{b}$ \\
\hline Bcl-2 & $0.63 \pm 0.12^{c}$ & $3.11 \pm 0.24^{\mathrm{a}}$ & $1.35 \pm 0.12^{b}$ \\
\hline Bax & $0.45 \pm 0.03^{c}$ & $1.13 \pm 0.11^{\mathrm{a}}$ & $0.78 \pm 0.09^{b}$ \\
\hline Caspase-3 & $0.62 \pm 0.14^{c}$ & $2.80 \pm 0.17^{\mathrm{a}}$ & $1.37 \pm 0.28^{b}$ \\
\hline Caspase-8 & $0.65 \pm 0.19^{c}$ & $2.31 \pm 0.15^{a}$ & $1.15 \pm 0.19^{b}$ \\
\hline Caspase-9 & $0.32 \pm 0.04^{c}$ & $1.59 \pm 0.26^{\mathrm{a}}$ & $0.63 \pm 0.04^{b}$ \\
\hline p53 & $0.73 \pm 0.15^{\mathrm{c}}$ & $2.52 \pm 0.18^{\mathrm{a}}$ & $1.27 \pm 0.15^{b}$ \\
\hline $\mathrm{Bcl}-2 / \mathrm{Bax}$ & $1.38 \pm 0.21^{\mathrm{c}}$ & $2.76 \pm 0.11^{\mathrm{a}}$ & $1.76 \pm 0.19^{b}$ \\
\hline \multicolumn{4}{|c|}{ Mean values with different letters were significantly different $(P<0.05)$. } \\
\hline \multicolumn{4}{|c|}{$\begin{array}{l}{ }^{1} \text { Diet: } \mathrm{LC}=\text { low concentrate diet; } \mathrm{HC}=\text { high concentrate diet; } \mathrm{HCN}=\mathrm{HC}+800 \mathrm{mg} / \mathrm{kg} \text { niacin in the feec } \\
\text { concentrate. }\end{array}$} \\
\hline
\end{tabular}

\section{Discussion}

In modern ruminant production, an increased proportion content in the diet is widely used to improve production performance and economic benefits. Nevertheless, $\mathrm{HC}$ diets tend to induce adverse effects on feed intake (Nagaraja and Titgemeyer 2007) and lead to an accumulation of VFA, reducing buffering capacity in the rumen ( $\mathrm{Li}$ et al. 2019). This promotes lower rumen $\mathrm{pH}$, reduces ruminal microbial diversity and ultimately results in SARA (Mccann et al. 2016; Oba and Allen 2000). In this study, the results showed that the $\mathrm{HC}$ diet reduced the rumen $\mathrm{pH}$ in sheep. Although the rumen $\mathrm{pH}$ value did not reach a rumen acidosis standard of below 5.8 (Gozho et al. 2005), digestive disturbances still occurred, as evidenced by the reduced feed intake and high content of lactic acid in the rumen of the sheep. The HC diet supplemented with niacin increased the rumen $\mathrm{pH}$ and decreased the lactic acid compared to the $\mathrm{HC}$ diet. As previously reported, niacin supplementation in $\mathrm{HC}$ diets of beef cattle can improve ruminal $\mathrm{pH}$ and propionate concentration, decrease the content of acetate, and promote the growth of rumen microorganisms (Doreau and Ottou 1996; Luo et al. 2019a; Niehoff et al. 2008). The beneficial effect of niacin may be partially ascribed to the regulation of niacin of the growth and community diversity of rumen microorganisms by inhibiting starch utilization and stimulating fibre degradation (Luo et al. 2017). 
It is unclear if a higher concentration of niacin would fully reverse the effects of a $\mathrm{HC}$ diet. However, the previous in vitro study in our research group showed that the addition of $20-80 \mathrm{mM}$ niacin attenuated cellular damage induced by butyrate and promoted cell proliferation. Higher concentrations $(100 \mathrm{mM})$ of niacin lead to low cell viability (Luo et al. 2019b).

Feeding an $\mathrm{HC}$ diet to ruminants results in a massive release of bacterial endotoxins (such as LPS), which provoke rumen epithelial cells to generate a amount of reactive oxygen species (ROS) (Arroyo et al. 2017). The ROS causes oxidative damage in mitochondrial proteins, DNA, and lipids, and decrease the activities of GSH-Px and SOD (Martínez-Alfaro et al. 2011; Terpilowska and Siwicki 2019; Wang et al. 2015). In the present study, the HC diet decreased the activities of CAT, GSH-Px, SOD, and T-AOC and increased the MDA content in the rumen epithelium compared to the LC diet, which was consistent with previous work. Niacin is an important antioxidant. It can inhibit nicotinamide adenine dinucleotide phosphate (NADPH) oxidase activity and reduce intracellular ROS production (Ganji et al. 2015). One previous review has summarized that niacin can effectively reduce the cellular ROS concentration, improve the activities of GSH-Px and CAT, and restore the activities of pyruvate dehydrogenase and succinate dehydrogenase (llkhani et al. 2016). Similarly, the HC diet supplemented with niacin increased the activities of CAT, GSH-Px, and T-AOC and decreased the MDA content.

The rumen mucosa, an important physiological barrier between rumen internal environment and blood circulation system, can effectively prevent various pathogens and harmful substances from entering blood (Plaizier et al. 2012). When rumen mucosal integrity is damaged, the functions of rumen digestion, absorption, and epithelial barriers are impaired (John et al. 2011). In this study, we observed that the rumen papillae length, width, and cuticular layer thickness in sheep fed with a $\mathrm{HC}$ diet were lower than in sheep fed a LC diet. This result was consistent with earlier reports suggesting that during SARA, exposure to an acidic environment coupled with high rumen LPS concentrations work together to cause rumen epithelial damage, resulting in a decrease in rumen papillae length, width, and cuticular layer (Hu 2008). In the present study, adding niacin to the $\mathrm{HC}$ diet increased the rumen papillae length, width, and cuticular layer thickness compared to the HC diet. The development of SARA is accompanied by inflammatory reaction, which due to that the destruction of ruminal epithelium, leading to abnormal harmful substances from the rumen entering the blood and resulting in an up-regulation of serum inflammatory cytokines by epithelial leakage (Dong et al. 2013; Plaizier et al. 2012). The results in the present study showed that the $\mathrm{HC}$ diet increased the serum inflammatory cytokines compared to the LC diet, and adding niacin to the $\mathrm{HC}$ diet decreased these factors. This effect may be partially due to niacin playing an antiinflammatory role by reducing multiple inflammatory factors (including IL-6, TNF-a, and iNOS) via inhibition of the NF-KB signaling pathway (Chen et al. 2009).

The molecular mechanism underlying niacin regulation of rumen epithelial papillae morphology is not clear. It is well known that the stability of rumen epithelial cells depends on a specific balance between cellular apoptosis and proliferation. In the current study, the HC diet increased the apoptotic index of rumen epithelial cells in sheep over the LC diet, which might suggest that the disruption of the rumen mucosal barrier is associated with rumen epithelial cell apoptosis induced by the HC diet. Dai et al. 
(2020) demonstrated that a high grain diet could promote rumen epithelial cell apoptosis in dairy cows. During SARA, the rumen is in a state of abnormal stress due to the accumulation of organic acids and the decrease in $\mathrm{pH}$, which may result in an increase in the apoptosis of rumen epithelial cells. Similarly, acetic acid-induced mucosal injury in a rat model is often used to study the therapeutic effects of anti-apoptotic drugs on gastric ulcers ( $\mathrm{Li}$ et al. 2017; Nakamura et al. 2003). When the content of butyrate exceeds the rumen papillae absorbing ability, it will inhibit the proliferation of epithelial cells (Luo et al. 2019b). In this study, niacin supplementation in the $\mathrm{HC}$ diet decreased the apoptotic index of rumen epithelial cells. It is suggested that lower VFA (especially of butyrate) and higher ruminal pH in sheep in the HCN treatment may be responsible for stress relief in the rumen epithelium.

As a cascade reaction, apoptosis is regulated by intracellular genes and extracellular factors (Bergmann 2007). Among the many apoptosis-related genes, Fas, Bcl-2, and Bax have attracted more attention in the literature. Fas (also known as Apo-1/CD95) an one cell surface protein, belongs to the tumor necrosis factor (TNF)/nerve growth factor receptor family. Fas activation by FasL and its receptor (Fas-associated death domain, FADD) activate caspases-3, -8 , and - 9, leading to apoptosis (Freiberg et al. 1996; Hodge et al. 1998; Walker et al. 1998). Bcl-2 is highly homologous to Bax. Expression of Bcl-2 has been shown to suppress apoptosis, whereas Bax promotes apoptosis in response to different stimuli, and a high Bcl2/Bax ratio indicates resistance to apoptosis (Zhang et al. 2011). A crucial tumor suppressor protein, p53 plays a vital role in inducing cell cycle arrest, DNA repair, and apoptosis (Thakur et al. 2012). Previous studies have revealed that a medium concentrate diet (35\% concentrate) increased the mRNA expression of apoptotic genes (caspase-3, caspase-8, caspase-9, p53, and Bax), and reduced the ratio of Bcl-2 to Bax (BCl-2/Bax) expression compared to a LC diet (10\% concentrate) (Gui and Shen 2016). Similarly, in the present study, the $\mathrm{HC}$ diet increased the mRNA expression of rumen epithelium apoptosis-related genes (Fas, Bcl-2, Bax, Caspase-3, Caspase-8, Caspase-9, and p53) over the LC diet. However, Bcl-2/Bax expression in the $\mathrm{HC}$ group was elevated, probably because programmed cell death is not regulated by $\mathrm{Bcl}-2$ family proteins but rather depends on caspase activity and Cyt-C release. Niacin supplementation in the $\mathrm{HC}$ diet decreased the mRNA expression of apoptosis genes (Fas, Bcl-2, Bax, Caspase-3, Caspase-8, Caspase-9, and $p 53$ ). The down-regulation of apoptotic genes by niacin may be partially because niacin promotes ATP generation, DNA synthesis, and repair, and thereby improves the levels of cell viability (Kennedy 2016). Furthermore, oxidative stress-mediated by ROS is a well-known inducer of cell apoptosis (Raj et al. 2011). In this study, niacin increased the antioxidant capacity of rumen epithelium cells. It reduced the ROS production, which may contribute to the inhibition of apoptosis induced by the HC diet. More studies establishing the SARA model in vitro will be conducted soon to observe the effects of niacin on DNA repair and ROS generation in rumen epithelial cells, and to investigate the associated molecular signalling pathways to uncover the molecular mechanism of niacin in regulating rumen epithelial cell apoptosis.

In conclusion, the $\mathrm{HC}$ diet reduced the rumen $\mathrm{pH}$, decreased the rumen epithelial papillae morphology and size and antioxidant capacity, and increased the apoptotic index of rumen epithelial cells and apoptosisrelated gene expression, promoting the inflammatory response in sheep. Adding $800 \mathrm{mg} / \mathrm{kg}$ niacin tended 
to reverse the negative effects induced by the $\mathrm{HC}$ diet in terms of improving rumen epithelial papillae morphology and size, rumen epithelial antioxidant capacity, and inhibiting rumen epithelial cell apoptosis.

\section{Declarations}

\section{Authors' contributions}

Z.G., K.Ouyang. designed the overall study. Z.G., Y.L., C.X., D.L., Q.Q., K.P., X.X., M.Q. performed experiments. Z.G., Y.L. wrote the manuscript. All authors contributed to the article and approved the submitted version.

\section{Funding}

This work was funded by the National Natural Science Foundation of China (31560648), Jiangxi Provincial Cattle and Sheep Industry Technology \& System (JXARS-13), China Agriculture Research System of MOF and MARA.

\section{Data availability}

The datasets generated and analyzed during the current study are not publicly available due to all the results in the form of means and statistics are presented in this paper, but are available from the corresponding author on reasonable request.

\section{Code availability}

Not applicable.

\section{Ethics approval}

This study was approved by the Animal Care and Use Committee of the College of Animal Science and Technology of Jiangxi Agricultural University (JXAULL-2020-27).

\section{Consent to participate}

Authors have permission to participate.

\section{Consent for publication}

Authors have permission for publication.

\section{Competing interests}

The authors declare that they have no conflicts of interest.

\section{References}


1. Arroyo JM, Hosseini A, Zhou Z, Alharthi A, Trevisi E, Osorio JS, Loor JJ (2017) Reticulo-rumen mass, epithelium gene expression, and systemic biomarkers of metabolism and inflammation in Holstein dairy cows fed a high-energy diet. J Dairy Sci 100:9352-9360. https://doi.org/10.3168/jds.201712866

2. Bergmann A (2007) Autophagy and cell death: no longer at odds. Cell 131:1032-1034. https://doi.org/10.1016/j.cell.2007.11.027

3. Bühler S, Frahm J, Liermann W, Tienken R, Kersten S, Meyer U, Huber K, Dänicke S (2018) Effects of energy supply and nicotinic acid supplementation on phagocytosis and ROS production of blood immune cells of periparturient primi- and pluriparous dairy cows. Res Vet Sci 116:62-71. doi 10.1016/j.rvsc.2017.09.012.

4. Chen J, Cui X, Zacharek A, Ding GL, Shehadah A, Jiang Q, Lu M, Chopp M (2009) Niaspan treatment increases tumor necrosis factor-alpha-converting enzyme and promotes arteriogenesis after stroke. $J$ Cereb Blood Flow Metab 29:911-920. https://doi.org/10.1038/jcbfm.2009.11

5. Dai H, Ma N, Chang G, Aabdin ZU, Shen X (2020) Long-term high-concentrate diet feeding induces apoptosis of rumen epithelial cells and inflammation of rumen epithelium in dairy cows. Anim Biotechnol 3:1-8. doi 10.1080/10495398.2020.1806073.

6. Dong H, Wang S, Jia Y, Ni Y, Zhang Y, Zhuang S, Shen X, Zhao R (2013) Long-term effects of subacute ruminal acidosis (SARA) on milk quality and hepatic gene expression in lactating goats fed a high-concentrate diet. PLoS ONE 8(12):e82850. https://doi.org/10.1371/journal.pone.0082850

7. Doreau M, Ottou JF (1996) Influence of niacin supplementation on in vivo digestibility and ruminal digestion in dairy cows. J Dairy Sci 79(12):2247-2254. https://doi.org/10.3168/jds.S00220302(96)76601-8

8. Freiberg RA, Spencer DM, Choate KA, Peng PD, Schreiber SL, Crabtree GR, Khavari PA (1996) Specific triggering of the Fas signal transduction pathway in normal human keratinocytes. J Biol Chem 271:31666-31669. https://doi.org/10.1074/jbc.271.49.31666

9. Ganji SH, Kashyap ML, Kamanna VS (2015) Niacin inhibits fat accumulation, oxidative stress, and inflammatory cytokine IL-8 in cultured hepatocytes: Impact on non-alcoholic fatty liver disease. Metabolism 64:982-990. https://doi.org/10.1016/j.metabol.2015.05.002

10. Goad DW, Goad CL, Nagaraja TG (1998) Ruminal microbial and fermentative changes associated with experimentally induced subacute acidosis in steers. J Anim Sci 76:234-241. https://doi.org/10.2527/1998.761234x

11. Gozho GN, Plaizier JC, Krause DO, Kennedy AD, Wittenberg KM (2005) Subacute ruminal acidosis induces ruminal lipopolysaccharide endotoxin release and triggers an inflammatory response. $J$ Dairy Sci 88:1399-1403. https://doi.org/10.3168/jds.S0022-0302(05)72807-1

12. Gui $\mathrm{H}$, Shen $\mathrm{Z}$ (2016) Concentrate diet modulation of ruminal genes involved in cell proliferation and apoptosis is related to combined effects of short-chain fatty acid and $\mathrm{pH}$ in rumen of goats. J Dairy Sci 99:6627-6638. https://doi.org/10.3168/jds.2015-10446 
13. Günther C, Neumann H, Neurath MF, Becker C (2013) Apoptosis, necrosis and necroptosis: cell death regulation in the intestinal epithelium. Gut 62:1062-1071. doi 10.1136/gutjnl-2011-301364.

14. Hodge S, Novembre FJ, Whetter L, Gelbard HA, Dewhurst S (1998) Induction of fas ligand expression by an acutely lethal simian immunodeficiency virus, SIVsmmPBj14. Virology 252:354-363. https://doi.org/10.1006/viro.1998.9477

15. Hu HL (2008) Study on the nutritional and physiological mechanism of subacute ruminal acidosis in dairy goats [dissertation]. Hohhot(IM): Inner Mongolia Agricultural University

16. Ilkhani F, Hosseini B, Saedisomeolia A (2016) Niacin and oxidative stress: a mini-review. J Nutri Med Diet Care 2:014

17. John LJ, Fromm M, Schulzke J (2011) Epithelial barriers in intestinal inflammation. Antioxid. Redox. Sign. 15:1255-1270. ://doi.org/10.1089/ars.2011.3892.

18. Kennedy DO (2016) B vitamins and the brain: mechanisms, dose and efficacy-a review. Nutrients 8:68. https://doi.org/10.3390/nu8020068

19. Khafipour E, Krause DO, Plaizier JC (2009) A grain-based subacute ruminal acidosis challenge causes translocation of lipopolysaccharide and triggers inflammation. J Dairy Sci 92:1060-1070. https://doi.org/10.3168/jds.2008-1389

20. Li J, Wu X, Chen JL, Chen GR, Xu J, Gu Y, Song HP (2017) Antiplatelet drug ticagrelor delays gastric ulcer healing in rats. Exp Ther Med 14:3774-3779. https://doi.org/10.3892/etm.2017.4955

21. Li W, Gelsinger S, Edwards A, Riehle C, Koch D (2019) Transcriptome analysis of rumen epithelium and meta-transcriptome analysis of rumen epimural microbial community in young calves with feed induced acidosis. Sci Rep-UK 9:4744

22. Li Y, Shang H, Zhao X, Qu M, Peng T, Guo B, Hu Y, Song X (2021) Radix Puerarin extract (Puerarin) could improve meat quality of heat-stressed beef cattle through changing muscle antioxidant ability and fiber characteristics. Front Vet Sci 7:615086. https://doi.org/10.3389/fvets.2020.615086

23. Luo D, Gao Y, Lu Y, Qu M, Xiong X, Xu L, Zhao X, Pan K, Ouyang K (2017) Niacin alters the ruminal microbial composition of cattle under high-concentrate condition. Anim Nutr 3:92-97

24. Luo D, Gao Y, Lu Y, Zhang Q, Qu M, Xiong X, Xu L, Zhao X, Pan K, Ouyang K (2019a) Niacin supplementation improves growth performance and nutrient utilisation in Chinese Jinjiang cattle. Ital J Anim Sci 18:57-62. https://doi.org/10.1080/1828051X.2018.1480426

25. Luo D, Peng Z, Yang L, Qu M, Xiong X, Xu L, Zhao X, Pan K, Ouyang K (2019b) Niacin protects against butyrate-induced apoptosis in rumen epithelial cells. Oxid Med Cell Longev 3:1-8. https://doi.org/10.1155/2019/2179738

26. Mao SY, Huo WJ, Zhu WY (2015) Microbiome-metabolome analysis reveals unhealthy alterations in the composition and metabolism of ruminal microbiota with increasing dietary grain in a goat model. Environ Microbiol 18:525-541. https://doi.org/10.1111/1462-2920.12724

27. Martínez-Alfaro M, Alcaraz-Contreras Y, Cárabez-Trejo A, Leo-Amador GE (2011) Oxidative stress effects of thinner inhalation. J Occup Environ Med 15:87-92. https://doi.org/10.4103/00195278.93195 
28. Mccann JC, Luan S, Cardoso FC, Derakhshani H, Khafipour E, Loor JJ (2016) Induction of subacute ruminal acidosis affects the ruminal microbiome and epithelium. Front Microbiol 7:701. https://doi.org/10.3389/fmicb.2016.00701

29. Nagaraja TG, Titgemeyer EC (2007) Ruminal acidosis in beef cattle: the current microbiological and nutritional outlook. J Dairy Sci 90:E17-E38. https://doi.org/10.3168/jds.2006-478

30. Nakamura M, Akiba Y, Matsui H, Tsuchimoto K, Ishii H (2003) Rebamipide binds to iNOS-positive cells in acetic acid-treated but not in ethanol-treated rat gastric mucosa. Aliment Pharm Ther 18:7681. https://doi.org/10.1046/j.1365-2036.18.s1.8.x

31. Niehoff I, Hüther L, Lebzien $P$ (2008) Niacin for dairy cattle: a review. Brit J Nutr 101:5-19. https://doi.org/10.1017/S0007114508043377

32. Oba M, Allen MS (2000) Effects of brown midrib 3 mutation in corn silage on productivity of dairy cows fed two concentrations of dietary neutral detergent fiber: 3 . digestibility and microbial efficiency. J Dairy Sci 83:1350-1358. https://doi.org/10.3168/jds.S0022-0302(00)75001-6

33. Plaizier JC, Khafipour E, Li S, Gozho GN, Krause D (2012) Subacute ruminal acidosis (SARA), endotoxins and health consequences. Anim Feed Sci Tech 172:9-21. https://doi.org/10.1016/j.anifeedsci.2011.12.004

34. Raj L, Ide T, Gurkar AU et al (2011) Selective killing of cancer cells by a small molecule targeting the stress response to ROS. Nature 475:231-234. https://doi.org/10.1038/nature10789

35. Sun YY, Cheng M, Xu M, Song LW, Gao M, Hu HL (2018) The effects of subacute ruminal acidosis on rumen epithelium barrier function in dairy goats. Small Ruminant Res 1-7. https://doi.org/10.1016/j.smallrumres.2018.09.017

36. Tang K, Sham H, Hui E, Kirkland JB (2008) Niacin deficiency causes oxidative stress in rat bone marrow cells but not through decreased NADPH or glutathione status. J Nutr Biochem 19:746-753. https://doi.org/10.1016/j.jnutbio.2007.10.003

37. Terpilowska S, Siwicki AK (2019) Cell cycle and transmembrane mitochondrial potential analysis after treatment with chromium(iii), iron(iii), molybdenum(iii) or nickel(ii) and their mixtures. Toxicol Res-UK 8:188-195. https://doi.org/10.1039/c8tx00233a

38. Thakur VS, Gupta K, Gupta S (2012) Green tea polyphenols increase p53 transcriptional activity and acetylation by suppressing class I histone deacetylases. Int J Oncol 41:353-361. https://doi.org/10.3892/ijo.2012.1449

39. Walker PR, Saas P, Dietrich P (1998) Tumor expression of Fas ligand (CD95L) and the consequences. Curr Opin in Immunol 10:564-572. https://doi.org/10.1016/S0952-7915(98)80225-2

40. Wang J, Zhang H, Zhang T, Zhang R, Liu R, Chen Y (2015) Molecular mechanism on cadmiuminduced activity changes of catalase and superoxide dismutase. Int J Biol Macromol 77:59-67. https://doi.org/10.1016/j.jibiomac.2015.02.037

41. Wang Y, Tian Z, Shi H, Zhong J, Ren G, Li Y, Liu Y, Wu Q, Wang J, Zhang Z, Ding K, Yu Z, Zhao Z (2017) Nutritional characteristics and muscle fiber histological characters of muscle from Hu sheep. Chinese Journal of Animal Nutrition 29:2867-2874 
42. Zhang H, Liu Y, Lao M, Ma Z, Yi X (2011) Puerarin protects Alzheimer's disease neuronal cybrids from oxidant-stress induced apoptosis by inhibiting pro-death signaling pathways. Exp Gerontol 46:3037. https://doi.org/10.1016/j.exger.2010.09.013

43. Zhang L, Yue HY, Wu SG, Xu L, Zhang HJ, Yan HJ, Cao YL, Gong YS, Qi GH (2010) Transport stress in broilers. II. Superoxide production, adenosine phosphate concentrations, and mRNA levels of avian uncoupling protein, avian adenine nucleotide translocator, and avian peroxisome proliferatoractivated receptor-y coactivator-1a in skeletal muscles. Poultry Sci 89:393-400. https://doi.org/10.3382/ps.2009-00281

\section{Figures}

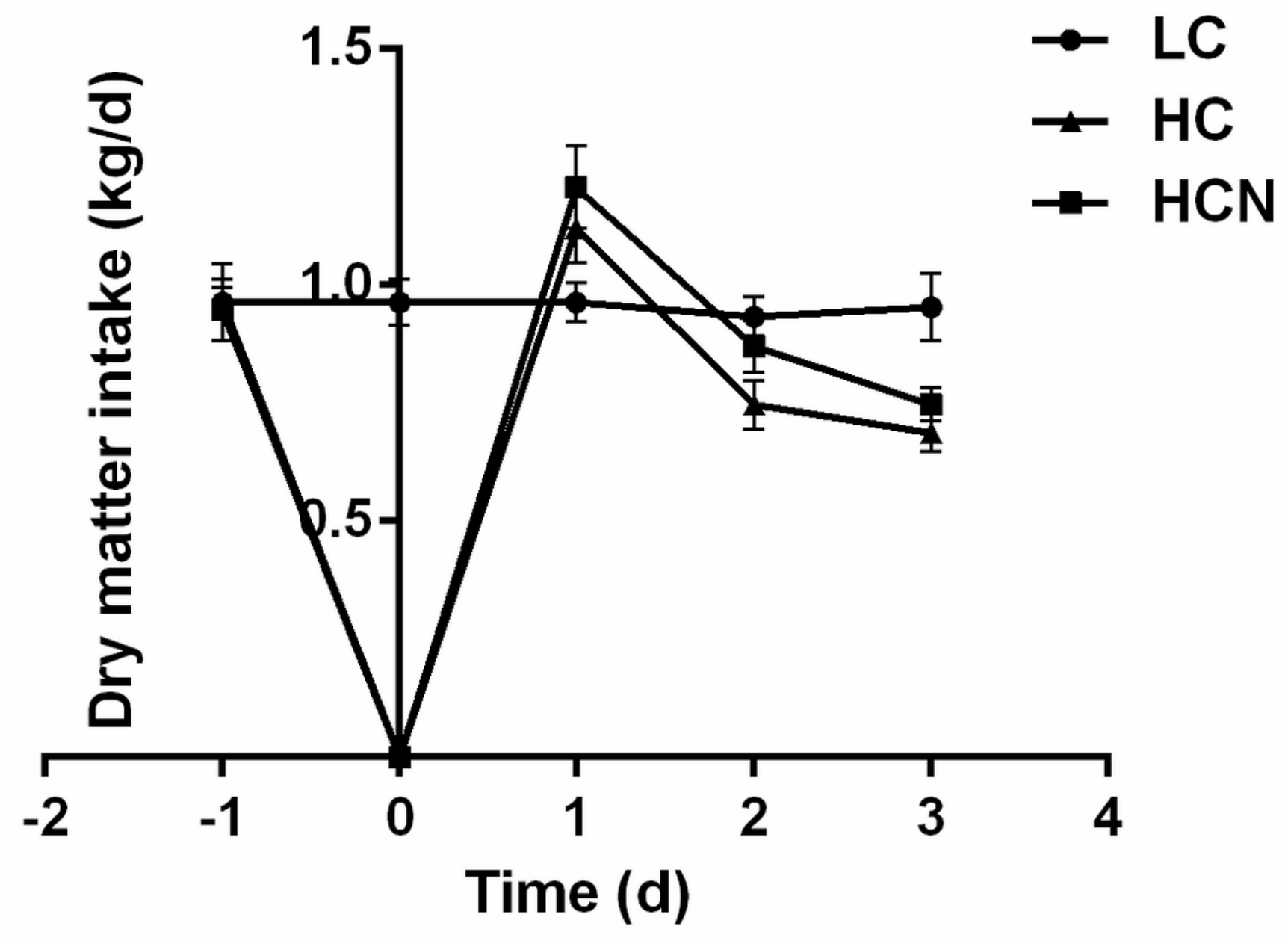

Figure 1

Effects of diet treatments on the dry matter intake of sheep LC = low concentrate diet; $\mathrm{HC}=$ high concentrate diet; $\mathrm{HCN}=\mathrm{HC}+800 \mathrm{mg} / \mathrm{kg}$ niacin in the feed concentrate. On the x-axis, $-1 \mathrm{~d}$ mean the 7th day of the pre-trial period, $0 \mathrm{~d}$ mean the day of fast, and $1 \mathrm{~d}, 2 \mathrm{~d}, 3 \mathrm{~d}$ means the three days of the 
experimental period. At the last stage of the pre-trial period, the feed intake of each groups was closed. Only the 7th day of the pre-trial period was showed on the table.

(a)

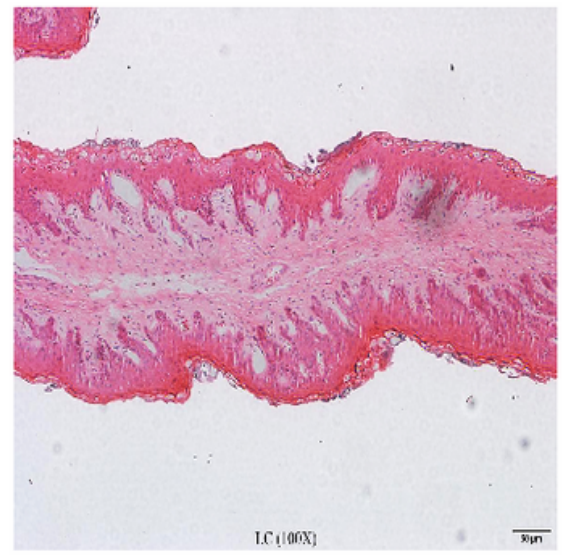

LC $(\times 100)$

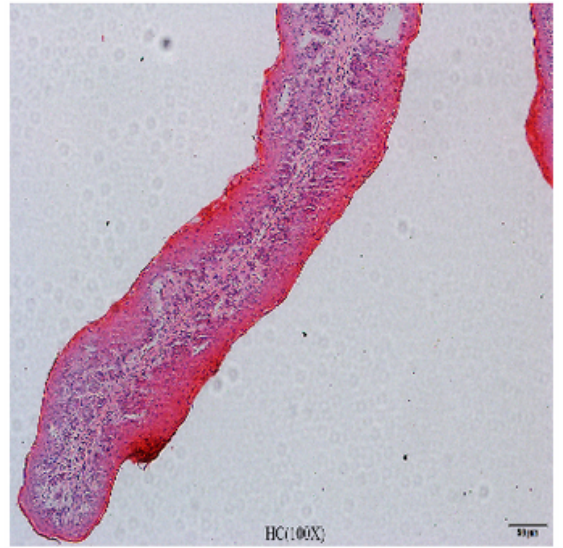

$\mathrm{HC}(\times 100)$

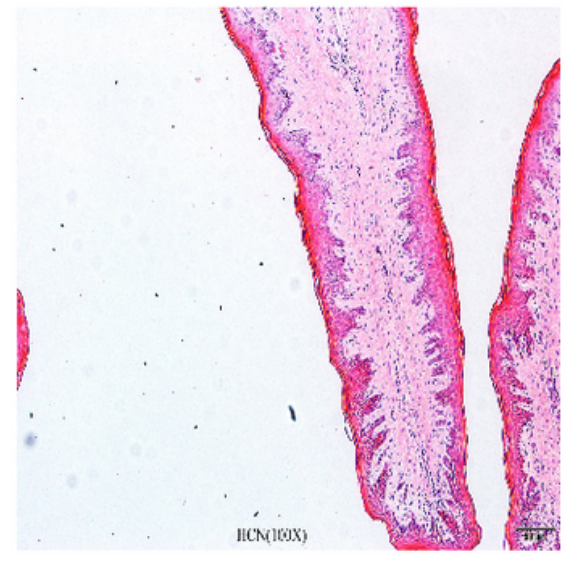

$\mathrm{HCN}(\times 100)$
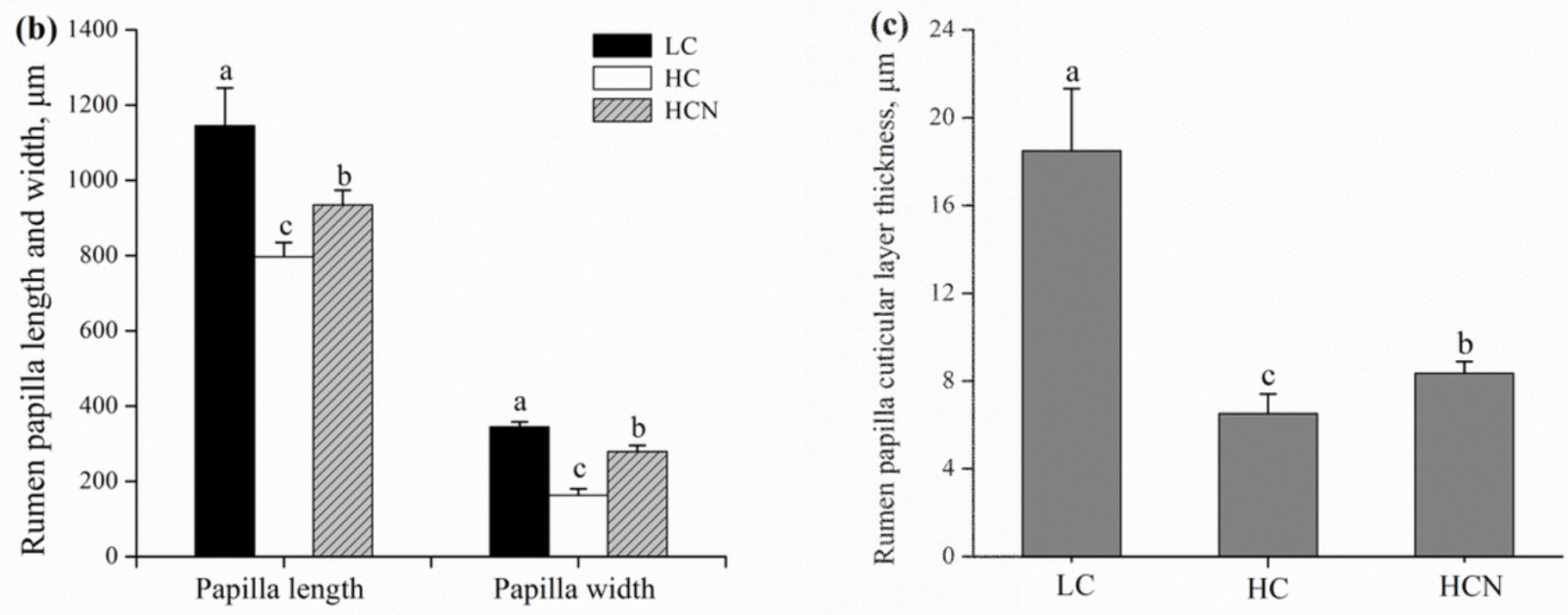

Figure 2

Effects of diet treatments on the rumen papilla morphology (a), papilla length and papilla width (b) and papilla cuticular layer thickness (c) in sheep ( $\square$ ): LC = low concentrate diet; $(\square)$ : HC = high concentrate diet; ( ): $\mathrm{HCN}=\mathrm{HC}+800 \mathrm{mg} / \mathrm{kg}$ niacin in the feed concentrate. a,bMean values within different letters were significantly different $(P<0.05)$. 
(a)

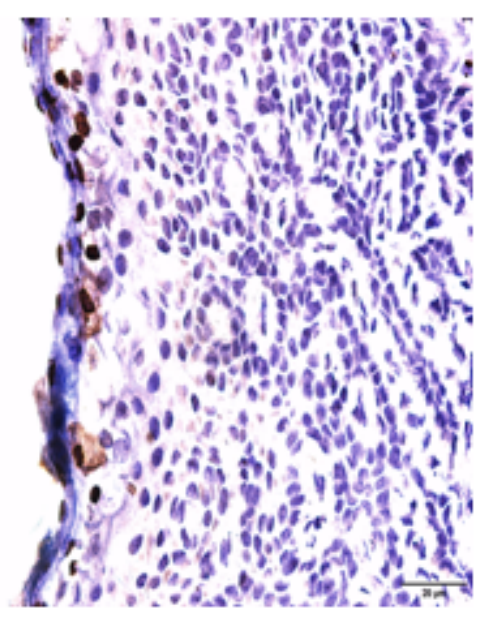

$\mathrm{LC}(\times 400)$

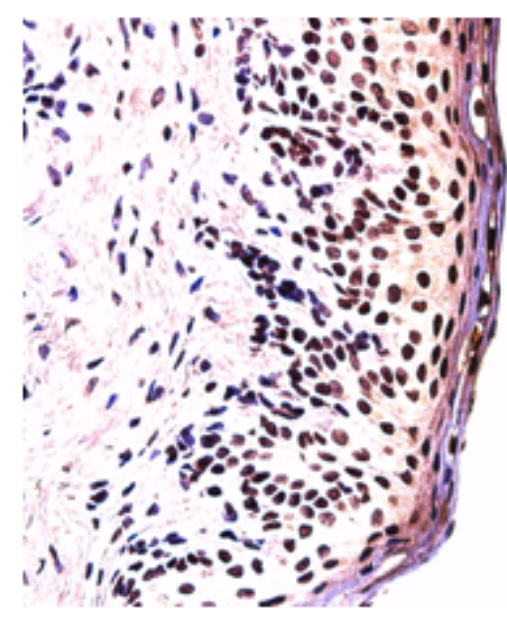

$\mathrm{HC}(\times 400)$

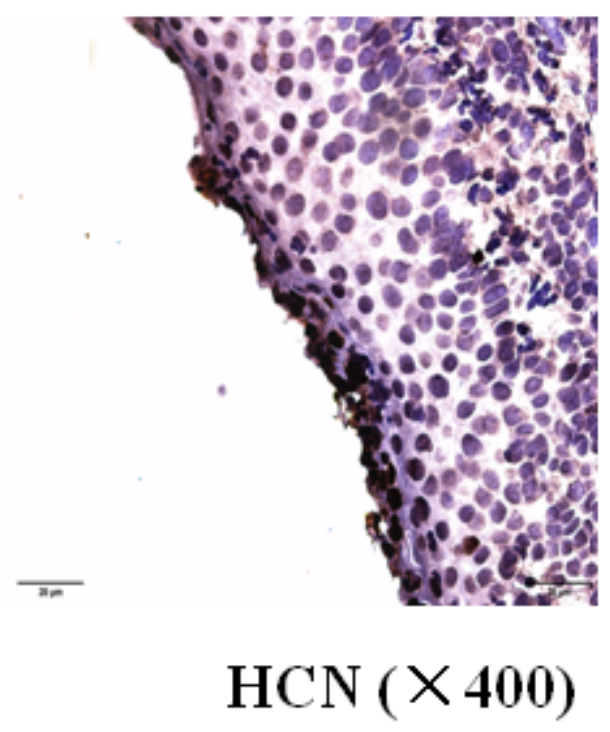

(b)

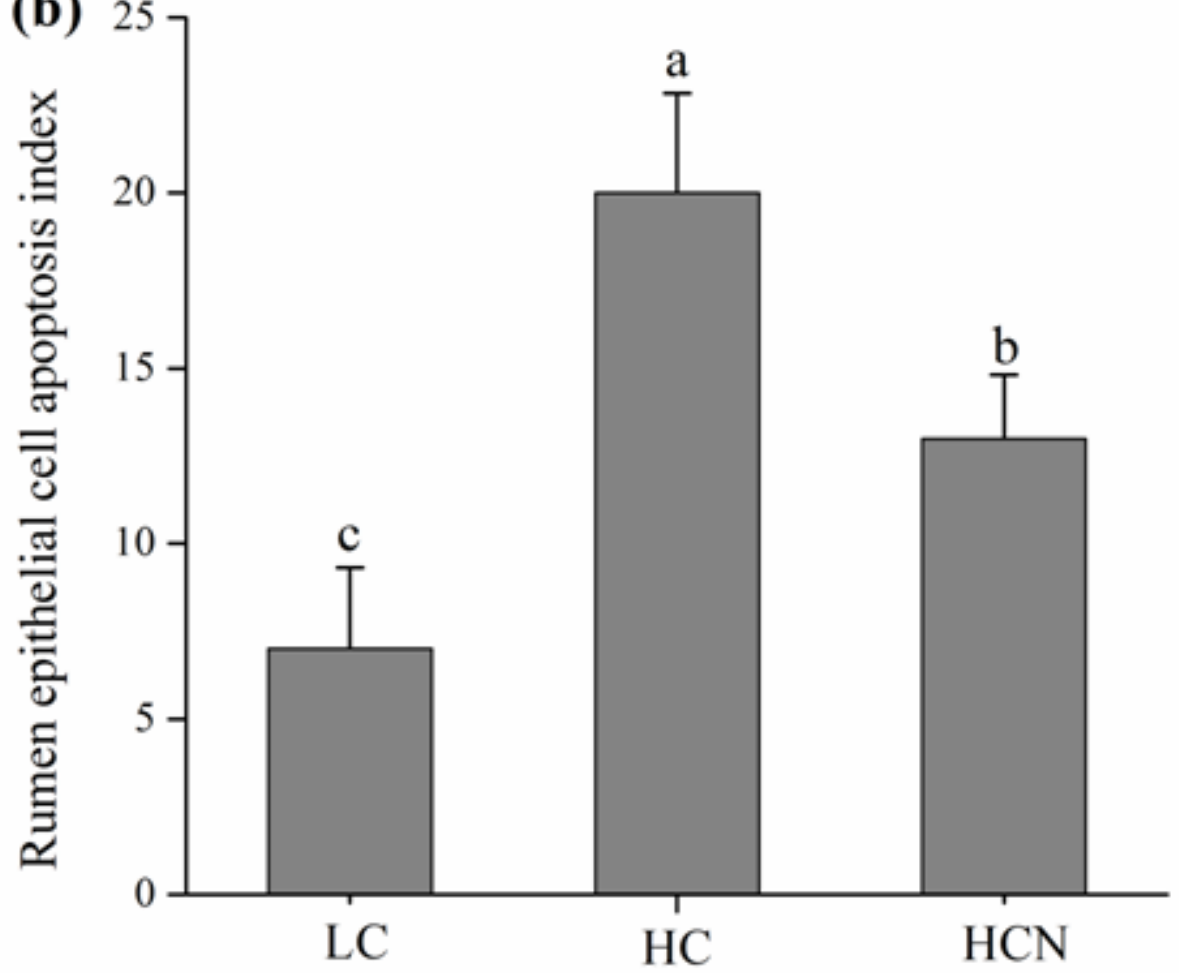

Figure 3

Effects of diet treatments on the rumen epithelium cell apoptosis (density plots) (a) and apoptosis index (b) in sheep. $\mathrm{LC}=$ low concentrate diet; $\mathrm{HC}=$ high concentrate diet; $\mathrm{HCN}=\mathrm{HC}+800 \mathrm{mg} / \mathrm{kg}$ niacin in the feed concentrate. a,bMean values within different letters were significantly different $(P<0.05)$. 